\title{
THE IMPLEMENTATION OF E-LEARNING WITH TEAM BUILDER AT VOCATIONAL HIGH SCHOOLS
}

\author{
${ }^{1)} \mathrm{Mahmud} \mathrm{Al}$ Haq Patwary; ${ }^{2}$ Herman Dwi Surjono \\ ${ }^{1)}$ Hubdhaka, Bangladesh; ${ }^{2)}$ Yogyakarta State University, Indonesia \\ ${ }^{1)}$ emon_ierdu@yahoo.com; ${ }^{2}$ hermansurjono@uny.ac.id
}

\begin{abstract}
This research is aimed at: (1) producing an appropriate e-learning for English language studies in vocational high school, (2) evaluating the suitability of the developed e-learning in terms of appropriateness, accuracy and clarity, screen presentation and design, and appropriateness of the team builder module aspect, and (3) evaluating the effectiveness of the elearning in practical application. This research and development (R\&D) study used Alessi and Trollip's model rearranged following ADDIE model, where the development of instruction followed Dick and Carey's model and the need assessment procedures were adapted from Lee \& Owens. Overall appropriateness and quality of the e-learning from alpha testing is 'very appropriate' and from beta testing is 'excellent'. Alpha testing reveals that, the Team Builder Module is 'very appropriate' and beta testing reveals that, its overall quality is 'excellent'. The elearning is highly effective. The average score of the students raises 3.82 points (or $42.44 \%$ ) in the post-test from pre-test score. The minimum score of the post-test (i.e. 8) is more than the maximum score of the pre-test (i.e. 7), so it is concluded that the use of e-learning does not deteriorate the performance of the students, but improves their performance.
\end{abstract}

Keywords: implementation, e-learning, team builder, vocational high school 


\section{Introduction}

Nowadays, internet is a very widespread form of technology. Internet provides information effortlessly, effectively, and efficiently. Internet facilities should not only be treated as a medium of entertainment and social media, it should also be implemented to conduct consultations of learning difficulties, to give assignments, to conduct assessments, to carry out remedial programs, and to create interactive service activities among facilitators and learners in the development of instructional resources for the benefit of education. The debut of technology in learning spaces is altering the nature of transmission of instruction to the learners of primary to tertiary levels, which is progressively generating a new form of electronic literacy.

For the learners with exceptionalities technology, internet plays a significant role in education. Specially planned and adaptive technologies and media can contribute enormously in effective instruction of learners and can assist them to achieve their maximum potential regardless of their innate skills (Smaldino, Lowther, \& Russell, 2008, p. 5). E-learning-based instructional technologies as well as the emergence of online digital libraries are now substituting chalkboards. Internet, communication satellites, submarine fiber optics, and fully computer based learning arrangement in education expose that there has been a swing from industrialization to knowledge based societies. The rapid development of communication and information based technologies, with their enormous influence, has been very relevant in the technological shift. Subsequently, technology is foreseeing a transformation in the learning environment en route for a reliance on electronic sources to deliver instructional materials. With such alterations and the development of video conferencing and internet, the obstacles of remoteness are being smashed down at a rapid rate. Distance learning and e-learning has positive benefits of flexible delivery systems, which consents for consideration of new regions of learning.
Information and Communication Technology (ICT) can produce affirmative contributions to learners' learning and it is becoming even more widespread in our institutions (Muijs \& Reynolds, 2005, p. 222). It provides facilitators and learners with a range of exciting new possibilities for teaching and learning. ICT is a rapidly developing and promising field in education, as Muijs \& Reynolds (2005, p. 228) revealed:

ICT has been hypothesized to help pupils' learning in a number of ways... ICT in education provides pupils with unprecedented access to information on a range of topics through the use of internet. Interactivity and immediate feedbacks are further advantages of ICT in the classroom. Finally, ICT allows easy extension of learning from the classroom to the home.

In fact, in e-learning and distance education, more responsibility is being placed on the individual for his or her learning, instead of exclusively on the facilitator. Whilst educational technology is the study and ethical practice of facilitating learning and improve performance by creating, using, and managing appropriate technological processes and resources (Januszewski \& Molenda, 2008, p. 175) (AECT Definition and Terminology Committee, 2004). Nevertheless, for the implementation of technology, communication provides ample opportunities especially for the learners.

The use of technology in learning activities requires good planning. A transformation in the concept of the classroom in computer or internet is a new opportunity for learning in the context of the wider environment. Supplementary capability and connectivity inside a network makes more complex learning activities with the support of computer technology, information and communication in creating learning activities without being limited by such elements of place, space and time.

Barriers to learning at the school include monotonous learning resources, limitations of media in study, limited ability of facilitators and limited learning time in school. Using only lecture or discussion method learning materials typically provide 
learners only knowledge about the theory. Learners have difficulty in comprehending the knowledge gained, so that they tend to be less enthusiastic in learning. Limitations of conventional learning systems can be overcome with the use of information technology. Solution of the limitations of a medium of learning is the use of telecommunications facilities (internet, intranet, extranet) and multimedia (graphics, audio, video) as the main media in the transfer of content and interaction between teachers and learners. All those solutions are present in E-learning systems.

In most circumstances, English language teaching-learning process is based on abstract and memorization. Students are forced to memorize concepts devoid of any practical understanding. As a result, students often discover that English language studies learning processes are tedious, less pleasant, too much memorizing, lack in assortment, deficient in creativity, etc., and the instructional process is still teacher centered. In addition, the teachers found that most of the English language studies materials are not easy to clarify. Therefore, it is necessary to develop more interactive instructional program, like Alessi and Trollip (2001, p. 5) revealed:

\section{The field of instructional computing is still} young and evolving. Progress has been made, but much remains to be learned regarding the best ways to harness the power of computers. The proliferation of educational and training applications on the internet hopefully provides the momentum for people to take instructional multimedia more seriously. As this occurs, the amount of good materials for learning and instructional should increase.

In his book 'Teachers and Machines: The classroom use of technology since 1920', Cuban (1986) (as cited in Collis, Nikolova, \& Martcheva, 1995, p. 14) sharply analyses the introduction and use of technology in education:

Many educators have dreamed of making instruction both productive and enrichingwishing that children somehow could learn more and faster while teachers taught less. This dream has persisted from the invention of the lecture centuries ago to the early decades of this century when reformers sought efficiency through film, radio and television. The dream persists into the 1980s with promoters boosting desktop computers for each student...The promises implied in these aids educators' attention: individualized instruction, relief of the tedium of repetitive activities and presentation of content beyond what was available to a classroom teacher.

Current improvement in instructional design frequently involves Open Learning Systems, Computer-Assisted Instruction or Computer-Based Instruction, etc. In these modularized learning systems, not only does the control of the learning belongs to the learner, but also the designing of his or her learning setting. Learners' roles differ, but teachers also have to change their role from being instructor to facilitator. Technologies support teachers to play an effective and affective role in knowledge acquisition and knowledge construction of the learners.

The learning process is identical to the process of delivering information and communication. Learning activities require media that serve as a learning tool for conveying information. Learning aids that now need attention are computer and internet. Computers can stimulate students to acquire study materials, doing exercises and simulate activities since the easy obtainability of animation, graphics, color and sound. Computers can also support slow learners, for the reason that computer can offer a climate that is more effective in a more individualized so that learners do not easily fail to recall, under no circumstances bored, and enthuse to carry out instructions in accordance with the program used.

E-learning can optimize the utilization of computers to generate, display, and manipulate text, graphics, audio, images and to develop links and tools that allow users to steer, interact, and create and communicate. Through E-learning, learners can choose which parts to be studied in advance, students can also repeat the learning pace of their conformity to understand. It creates more dynamic and enthused learners. 
Tavangarian, et al (2004, p. 274) defined elearning as-

We will call e-Learning all forms of electronic supported learning and teaching, which are procedural in character and aim to effect the construction of knowledge with reference to individual experience, practice and knowledge of the learner. Information and communication systems, whether networked or not, serve as specific media (specific in the sense elaborated previously) to implement the learning process.

The advantages and benefits of delivering multimedia content to the concept of learning using internet is the learning process become more interesting and more interactive, the amount of instruction time can be reduced, the quality of learners' learning can be enriched and learners' learning attitudes can be enhanced, and learning process can be done anywhere and anytime. Learning with E-learning is expected to be conducted more effectively and interactively. This is due to each component of the E-learning can stimulate one or more human senses. In Eadge Dale's words:

Much of what we found to be true of direct and indirect experience, and of concrete and abstract experience, can be summarized in a pictorial device which we call the 'Cone of Experience.'... The cone device, then, is a visual metaphor of learning experiences, in which the various types of audio-visual materials are arranged in the order of increasing abstractness as one proceeds from direct experience... Exhibits are nearer to the pinnacle of the cone not because they are more difficult than field trips but only because they provide a more abstract experience. (Dale, 1954, p. 42)

E-learning is learning by using the facilities of electronic gadgets, especially computers. The learning procedure is supported by facilities such as computer technology, the internet, audio visual, and graphic media. E-learning can simply be understood as a learning procedure that utilizes information technology in the form of a computer equipped with telecommunication facilities (internet, intranet, extranet) and multimedia (graphics, audio, video) as the primary media delivery of content and interaction between instructor and learner. The development of e-learning in education inaugurated improvement of the effectiveness and flexibility of learning. The effectiveness of learning using e-learning tends to be alike when it is paralleled with orthodox or conventional learning, but the benefits that can be achieved by e-learning is in terms of flexibility. It is safe to assume that, because of these new technologies elearning will develop at a lightning fast rate. Whyte, C. B. (1989) studied the constantly growing part that computers would play in higher education. The evolution of blended learning using computers was been realized. Whyte predicted that, portable and handheld devices (e.g. laptop) that is minimized form of technology will continue in future replacing bulky and slow devices (e.g. desktop computer).

The use of e-learning is not totally new. The age of e-learning is almost same as the Web. According to IONESCU, A. (2012, p. 39):

At the beginning of 1960's the teachers of psychology from Stanford University Patrick Suppers and Richard C. Atkinson have experimented the use of computers for teaching mathematics and lecture for child in schools from East Paulo Alto, California. The Program Standford Education for Young Gifted has the beginnings in that early experiment. In 1963, Bernard Luskin had installed the first computer in a community college of industry and has worked to the development of instruction assisted on computers.

In this modern age of technology, where media is online-rich, it is outdated and not constantly appropriate to have educational resources largely conveyed as text. The mainstream of discussion forums in learning management systems are still in text, which appears to be at odds with the upsurge in the popularity of video, IMs, and other rich-media communications. Regarding this matter, Caladine (2008, p. 5) expressed:

There is an emerging body of literature that looks to the future of online learning and suggests that the most significant change will be away from monolithic LMSs to personal 
learning environments (PLEs). PLEs will take advantage of the high usage rate of the newer applications of the Web, in particular the social software applications that have been described as elements of Web 2.0. In this way e-learning 1.0, based on Web 1.0 will be make way for e-learning 2.0. PLEs will enable students to connect the Web 2.0 content they have developed previously or for personal purposes to an institutional virtual environment. This connection will then results in a larger environment and allow students to linke files in one application to another and so on.

A review of online learning by TallentRunnels et al. (2006) (as cited in Clark \& Mayer, 2011, p. 12) concurs:

Overwhelming evidence has shown that learning in an online environment can be as effective as that in traditional classrooms. Second, students' learning in the online environment is affected by the quality of online instruction. Not surprisingly, students in welldesigned and well-implemented online courses learned significantly more, and more effectively, than those in online courses where teaching and learning activities were not carefully planned and where the delivery and accessibility were impeded by technology problems.

E-learning at the schools in general was concerned to form Hypertext Markup Language (HTML) contents without management systems. The use of e-learning with the management system which is called Learning Content Management System (LCMS) brought drastic changes in instruction. Learning Management System (LMS) is a software application specially designed for the management, documentation, tracking, reporting and distribution of online education courses or training programs. LMSs vary from systems for organize trainings and educational records, to software for allocating online college courses over the internet. Most LMSs used by educational institutions are Webbased to enhance and support classroom teaching and to facilitate access to learning content by a larger population of learners across the globe.
Koperasi Vocational High School (SMK Koperasi) is a prominent vocational high school in Yogyakarta, Indonesia. With promising faculties and top of the class students, this school is achieving good results but students' performance is not up to the mark as intended. Using questionnaire, the researcher interviewed 23 teachers randomly out of 45 teachers and 104 students out of 120 students of class XI (the rest of the students were not present on the day that the interviews were conducted) of Koperasi Vocational High School.

All 104 students answered that teachers usually use only lecture method to deliver instruction and 62.5\% answered that the instructional process does not use any instructional media. Students lack motivation to current teaching-learning method, which is lecture method. In addition, 94.2\% answered that they feel not motivated to learn when learning materials are delivered using only traditional methods like lecture or discussion. Other 5.8\% answered that they feel very little motivated to learn when the teachers use only lecture or discussion. Besides, $82.7 \%$ students also stated that the current instructional process lacks variation in presenting the learning materials. From this finding, it can be assumed that regular academic activities of the school is monotonous. The repeated use of a method to deliver abstract materials can decrease students' motivation to learn. While discussing this matter, some students verbally expressed that the current process of presenting materials is monotonous and less attractive. To support learning process, according to $99 \%$ students, the existing instructional media is less than sufficient, and even $67.3 \%$ among them think it is very insufficient. The insufficient amount of instructional media can make learning process less interesting and can be hindrance for the learning process to achieve good quality. Among all students, $75 \%$ answered that instructional process rarely involves audio-visual materials and $96.2 \%$ students answered that audio-visual media that had been used was very difficult to use. Whereas, audio-visual materials have potential to make 
learning process of an abstract topic very interesting and easy, and the more frequent use of easy-to-use audio-visual materials can really help the learning process.

It was admitted by $34.8 \%$ teachers that they usually use lecture method in classroom and $60.9 \%$ admitted that they also use discussion method in classroom. In answering the question about the use of audio-visual materials in classroom, 56.5\% teachers admitted that they sometime use audio-visual materials in classroom, while $21.7 \%$ teachers admitted that they never used any audio-visual material to deliver instruction. Thus, 95.7\% teachers admitted that they use lecture and discussion method very frequent in classroom and less frequent or no use of audio-visual materials. This finding supports earlier opinions by students about learning process which is not having variety (see page 9) which can lead to noninteresting learning process and result in students' lacking motivation to learn.

It was revealed that $88.5 \%$ students access internet every day and $100 \%$ students own at least one internet enabled gadget. The researcher also observed that all of the students have Facebook and/or Twitter account and they seem to appear online from morning till night using internet-enabled hand phones. However, 45.2\% students answered that they never used internet to obtain any learning materials, $6.7 \%$ answered they rarely use internet to obtain learning materials and $31.7 \%$ answered they sometimes use internet to obtain learning materials. Among all students, 76\% answered that the school does not provide any facility for students to acquire learning materials using internet, while other $24 \%$ answered the school provides wireless internet access (WIFI) and there is a computer lab in school but the school does not provide any digital material or materials over the internet. While discussing this topic, students expressed that the use of internet and computer lab in school is not optimal because the school does not provide any e-learning facility via internet. In another question, $92.3 \%$ students expressed that an e-learning web site with a lot of facilities such as chat, forum, blog, assignment, learning materials, quiz, etc. will be beneficial in improving learning process.

The interview of teachers revealed that $30.4 \%$ teachers are regular internet user and $43.5 \%$ use internet once in a week. It is safe to say that $87 \%$ teachers use internet at least once in a month. Furthermore, 13\% teachers admitted that they never used internet. In another question, how frequent teachers use internet to obtain instructional materials, $65.2 \%$ teachers answered sometimes and $17.4 \%$ answered rarely, while $8.7 \%$ answered they never used internet to obtain instructional materials. According to $91.3 \%$ teachers, the school provides facilities for teachers to acquire instructional materials using the internet. They mentioned Wi-Fi as that facility. Meanwhile, $8.7 \%$ teachers did not give response to that question. Observation shows that all teachers own at least one internet-enabled device like hand phone, tablet PC, laptop or netbook, desktop PC, etc. In their interviews, $91.3 \%$ teachers made positive response that an e-learning website with facilities such as chat, forum, blog, assignment, learning materials, quiz, and etc. will help improving teaching-learning process. Thus, the school provides internet access, both teachers and students have electronic gadgets, but the whole system lacks an e-learning system which is not provided by the school, whereas all these elements can be combined to ensure a better, easier and interesting learning process by providing online learning materials.

In response to an interview question, $96.2 \%$ students think they are supervised by teachers only in school time and is not sufficient. It was expressed by $95.2 \%$ students that being able to conduct group study will benefit their learning process. Usually, teachers assign students to make groups based on their index number, but 99\% students expressed that they usually feel that their groups are not balanced and 100\% students agreed that it would be better if they can work in balanced groups. Negative responses were given by $73.9 \%$ teachers to the question about students' complaint of being supervised by the teachers only in school time that is sufficient for students. In 
answering the question about students' group study, 95.7\% teachers agreed that being able to conduct group study is beneficial to students' learning process. They also agreed that while assigning group task, they usually feel that the groups are not balanced and it will improve students' performance if students can work in balanced groups. Group studying can increase cooperation between students but working in a not balanced group can severely affect the quality of learning. If all members of a group are very active, very interested to learn and each member has above average intelligence, that group can perform better. On the other hand, if all members of a group are not active, are careless about learning and all members have below average intelligence, the performance of that group can deteriorate. A group consisting of average intelligence members with average interest to learn and average activeness may not achieve improvement in their group performance.

To alleviate the current problems of learning, students need an easy-to-use media which can be accessed by their presently owned devices without extra cost, to obtain interesting learning materials, and to be able to work in balanced groups for group studies. Meanwhile, teachers need a medium which requires less technical knowledge and can be accessed using their presently owned devices, to provide learning materials, and also a tool to easily create balanced groups for students' group studies.

Based on the background that has been presented, the following issues had been identified: Koperasi Vocational High School does not have an e-learning system and it requires to develop an e-learning system. The use of digital instructional media for English language studies learning is not sufficient, not attractive and not easy to use. The use of internet facility and computer laboratory is not optimal. The use of technology for learning activities in current system is not systematic or difficult to use. The groups which are made for group study are not balanced.

The problems in this study were focused to issues concerning the use of technology in learning activities, the presentation of learning materials that are less attractive and less accessable, the limitations of the use of digital learning media and the limited ability of schools to develop and apply learning with e-learning, the notoptimal-use of internet-computer resources, and the absence of balanced groups for group studies. To avoid prodigiousness, due to the limited time, constraint of expenses and so forth, this research was limited to development of an e-learning system for Koperasi Vocational High School to provide students attractive and easy-to-use learning materials, to ensure sufficient use of digital instructional media for English language studies and optimal use of internet facility and computer laboratory. In addition, it is also focused on bringing the use of technology for learning activities under a structured system and providing facility for students to work in balanced groups.

Based on the identification of the problems that have been raised, then the problems were formulated as follows: (1) How to design and implement a Moodle 2.4 based e-learning system with team builder facility for the teachers and grade XI students of English language studies at Koperasi Vocational High School? (2) What is the level of appropriateness of the Moodle 2.4 based e-learning system with team builder facility for the teachers and grade XI students of English language studies at Koperasi Vocational High School? (3) How effective is the Moodle 2.4 based e-learning system with team builder facility for the grade XI students of English language studies at Koperasi Vocational High School?

The objectives of this study were: (1) To design and implement a Moodle 2.4 based e-learning system with team builder facility for the teachers and grade XI students of English language studies at Koperasi Vocational High School; (2) to reveal the level of appropriateness of the Moodle 2.4 based e-learning system with team builder facility for the teachers and grade XI students of English language studies at Koperasi Vocational High School; (3) to determine the effectiveness of the Moodle 2.4 based e- 
learning system with team builder facility for the grade XI students of English language studies at Koperasi Vocational High School, Yogyakarta, Indonesia.

For the purpose of the development of e-learning in Koperasi Vocational High School, the researcher selected an open source LMS Moodle 2.4.4 which was stable release of Moodle core released in 14 May 2013. Moodle (acronym for Modular ObjectOriented Dynamic Learning Environment) is a free source e-learning software platform, also known as a Learning Management System, or Virtual Learning Environment (VLE). The researcher chose this LMS because it is the number one open source LMS of the time. Statistics shows as of June 2013 it had a user base of 83,008 registered and verified sites, serving 70,696,570 users in $7.5+$ million courses with $1.2+$ million teachers (Moodle Statistics, 2013). Besides, the philosophy of Moodle (Philosophy MoodleDocs, n.d.) includes a constructivist and social constructionist approach to education, emphasizing that learners (and not just teachers) can contribute to the educational experience. Using these pedagogical principles, Moodle provides a flexible environment for learning communities (Moodle | Moodlerooms, n.d.). The product was developed on LAMP (Linux, Apache, MySQL and PHP) platform because in Moodle developers' opinion, it is the safest combination. (Moodle community, 2012). Three gigabyte disk space and one gigabyte RAM were allocated to run the product on shared hosting service. In order to access e-learning system, users need a modern browser (e.g. Mozilla Firefox, Safari, etc.), stable internet connection and any internet-enabled device to access it (e.g. smartphone, tablet PC, laptop, desktop PC, etc.). Primary contents of the e-learning site are three important topics of English language studies for class XI of vocational high school level in Indonesia, namely invitation-response, bargain-response and asking and giving opinion. Later, teachers of Koperasi Vocational High School are expected to enhance the site with more contents of English language studies and other subjects.

The study was envisaged of being beneficial in two facets: theoretical and practical. At the outset, theoretically, the study would help to impart knowledge on the concept, theories and methods of instructional technologies amid e-learning in the school ambiance and would provide ideas on how we can implement and improve instructional multimedia using e-learning in vocational high schools. Some benefits of the Interactive Instructional e-learning portal of this Research and Development are listed below. Practical benefits for the students are: The e-learning provides additional help in understanding the subject matters, especially English language studies. The e-learning portal provides students an effective and flexible learning medium. As the e-learning is an attractive and not monotonous media, it upsurges students' enthusiasm to learn. As this platform is optimized for group study, group users gain benefit from it. The team builder module yield balanced groups for group studies, hence, it improves learning outcomes by enhancing group dynamics. Practical benefits for the teachers are: It is easier to distribute both multimedia and nonmultimedia learning materials using e-learning so it simplifies the process of delivering subject matters. It is easier to amend elearning course materials using e-learning, hence, it improves the excellence of teaching. E-learning simplifies the management of teaching and learning activities. The effort to create balanced groups for group studies reduces to bare bones so it helps teachers to save time and energy for other activities. For the school, e-learning system is assumed to improve the learning processes of the entire school with more organized courses, improved teaching, and dynamic and motivated students.

In theoretical benefits, for researchers, this product opens a new way for further research. Therefore, it is a decent source for other researchers. It crafts a platform and reference on which other education researchers could continue on the effectiveness of this study or the product. 
The results of this study are anticipated to contribute additional insight into the experience and knowledge in the practice of theory of education and e-learning. For the State University of Yogyakarta, the results of this study are expected to add their repertoire of reading and knowledge of e-learning systems as well as a study reference for students of State University of Yogyakarta. As this Instructional Multimedia is computer based, hence, it is helpful to the related professionals as well to the students of the fields.

The following additional benefits are also expected: Teaching-learning process can be optimized through the implementation of technology for education. Communication dynamics between teachers and students can be increased by the facilities which are provided in the e-learning, such as chats, forums, blogs, etc. Collaborative learning increases, which improves the whole learning process. The development of e-Learning in Koperasi Vocational High School may encourage other schools to improve their teaching learning process by implementing eLearning.

The assumptions of this development were as follows: The instruments which were used were valid and reliable instruments. The method is appropriate to the problem which was being addressed and the purpose of the study. In order to measure the effectiveness of the e-learning, the difference between the average score of the students before implementing the e-learning (pre-test) and the average score of students after implementing the e-learning (post-test) is sufficient. Implementing the e-learning in one grade (out of three) is adequate to find its appropriateness and effectiveness. Participants of the beta-testing (both teachers and students) are representative of their respective populations and they were willing and honest in evaluating the e-learning. The results about effectiveness and appropriateness of the e-learning are generalizable beyond the grade XI of Koperasi Vocational High School. The elearning will be appropriate and effective for the teachers and students of Koperasi
Vocational High School. Teachers of Koperasi Vocational High School will enhance the site with more contents of English language studies and other subjects. The e-learning will assist students to achieve their maximum potential. The e-learning will become a flexible system to deliver instruction and learning materials. It will provide teachers and students a range of exciting new possibilities for teaching and learning. Students monotony in learning will be alleviate by the use of attractive audiovisual materials which are provided using the e-learning and it will motivate them to study. More use of audio-visual materials will provide additional help in understanding abstract subject matters of English language studies. The use of the e-learning will optimize the use of available computer and internet facilities. The use of Team Builder module in e-learning will improve group dynamics resulting in effective group studies, and will promote collaborative learning by increasing cooperation between students. Team Builder module will help teachers to save time and energy for other instructional activities. The e-learning system will provide a structured system to use technology in instructional and learning activities.

The limitations of this development were as follows: The results of this study are limited by the accuracy of the theoretical framework on e-learning development and implementation. While measuring students' performance hence the effectiveness of the elearning, extraneous variables (e.g. time of the day, classroom environment, etc.) were not considered. The results of this study are limited by the ability of the method and models used. The use of other methods and models for the same study may produce different results. The results of this study are limited to averages of scores, which is appropriate to address the research questions but the use of other statistics may determine different conclusions. The study was limited to one selected vocational high school (Koperasi Vocational High School) in Yogyakarta, Indonesia. The study was only limit to single competency. In order to evade immensity, the study took only the formative 
evaluation. All procedures were selected purposively. The large-scale practical application or the effectiveness of the instruction was not evaluated.

Vocational High School (Sekolah Menengah Kejuruan - SMK), is a secondary education school system in formal education in Indonesia after graduating from junior high school (or equivalent). Vocational high school is normally taken within 3 or 4 years, ranging from grade 10 to grade 12 .

\section{Method}

Type of Research

This research employed the Research and Development ( $R$ \& $\mathrm{D})$ approach. Research and development of education is a process used to develop and test validation or feasibility of a product after the product is developed. This R \& D study produced an elearning for the vocational high school students. The anticipated product of this $\mathrm{R} \& \mathrm{D}$ was an online e-learning portal.

Time and Place of Research

The study was conducted from November 2012 to August 2013. The research was conducted at the selected vocational high school, which is, Koperasi Vocational High School, which is located in Yogyakarta, Indonesia.

Subject of the Research

The subject of this research and development ( $\mathrm{R} \& \mathrm{D}$ research) was the grade XI students of the Koperasi Vocational High School, Yogyakarta, Indonesia; while the research was aimed at developing an elearning portal with team builder facility for English language studies at vocational high school in Yogyakarta. The school was identified according to the need analysis procedures.. The respondents of this research were 9 teachers and 48 students of class XI of Koperasi Vocational High School, Yogyakarta, Indonesia.

Research Procedure

This research and development $(\mathrm{R} \&$ D) study used Alessi and Trollip's model rearranged following ADDIE model, where the development of instruction followed Dick and Carey's model and the need assessment procedures were adapted from Lee \& Owen. The development of the elearning was conducted in six phases, explicitly: analysis, planning, design, development, implementation and evaluation. The Alpha testing of the product was done by two experts. The field testing of the study was done in Koperasi Vocational High School, Yogyakarta, Indonesia, where 50 students of class XI and 9 teachers participated for beta testing. The primary contents of the e-learning were topics of English language studies for class XI. The data from the evaluation and need assessment were collected using printed questionnaires, test and through interviews. The product testing for this study was conducted consisting of three phases: Expert judgments as validation from content \& instructional expert, and media specialist to measure appropriateness of the e-learning (alpha testing); Evaluation by e-learning users (both teachers and students) to measure appropriateness of the e-learning (beta testing); Pre-test and post-test for the students in order to measure the effectiveness of the e-learning.

Data, Instrument, and Data Collection Technique

Types of Data

This Research and Development developed an e-learning portal with team builder facility for the mentioned audiences. The required data were the quality of the elearning from the aspects of- (i) appropriateness, (ii) accuracy and clarity, (iii) screen presentation and design, and (iv) appropriateness of the team builder module and the effectiveness of the e-learning. The study also collected data on appropriateness of the instruments which were used for beta testing, contents, pre-test and post-test question, and team builder from two experts of the field.

\section{Data Collection Instrument}

In this research and development, data was collected through six types of 
questionnaires to measure the quality and appropriateness of the e-learning with team builder module: (a) Evaluation instrument for the content expert to measure the appropriateness of the contents of the elearning (alpha test), (b) evaluation instrument for the media specialist to measure the appropriateness of media aspects of the e-learning (alpha test), (c) evaluation instrument for both experts to measure the appropriateness of the instruments for beta testing, (d) evaluation instrument for the content expert to measure the appropriateness of the instrument for team builder and contents, (e) evaluation instrument for the teachers (beta test), and (f) evaluation instrument for the students (beta test).

In order to measure the effectiveness, the data were collected by using pre-test and post-test. In order to create balanced groups, a questionnaire was used through e-learning portal. For alpha testing, to collect experts' judgment on beta-testing instruments and to validate team builder instrument and contents, a binary scale was used, in which value 0 was represented by not appropriate or irrelevant and value 1 was represented by appropriate or relevant. For beta testing, a five-point Likert Scale was used. In order to know whether this e-learning was able to improve students' achievements, pre-test and post-test were carried out in the evaluation phase. The questions which were used in the pre-test and post-test were the same questions and they consisted of nine multiple choice questions.

\section{Data Analysis Technique}

The analysis that was mainly taken was a quantitative descriptive statistics analysis which involved gathering and interpreting this research and development. Thus, a binary scale and a five point Likert Scale were used. In the binary scale, value 0 was represented by not appropriate or irrelevant and value 1 was represented by appropriate or relevant. Those scores were converted to a five-point scale for fine graining according to Table 1.
Table 1. Conversion criteria for the binary scale

\begin{tabular}{ccc}
\hline Score Interval & \multicolumn{2}{c}{ Category } \\
\hline $\mathrm{X} \geq \overline{\mathrm{X}}+0.48 \mathrm{SD}$ & Very & Very \\
& Appropriate & Relevant \\
$\overline{\mathrm{X}}+0.16 \mathrm{SD}<\mathrm{X}<$ & Appropriate & Relevant \\
$\overline{\mathrm{X}}+0.48 \mathrm{SD}$ & & \\
$\overline{\mathrm{X}}-0.16 \mathrm{SD}<\mathrm{X}<$ & Neutral & Neutral \\
$\overline{\mathrm{X}}+0.16 \mathrm{SD}$ & & \\
$\overline{\mathrm{X}}-0.48 \mathrm{SD}<\mathrm{X}<$ & Inappropriate & Irrelevant \\
$\overline{\mathrm{X}}-0.16 \mathrm{SD}$ & & \\
$\mathrm{X} \leq \overline{\mathrm{X}}-0.48 \mathrm{SD}$ & Very & Very \\
& Inappropriate & Irrelevant \\
\hline
\end{tabular}

In table $1, \overline{\mathrm{X}}$ is mean and $\mathrm{SD}$ is standard deviation.

Based on the conversion in the Table 1 , the conversion of quantitative data to qualitative data is presented in Table 2.

Table 2. Conversion of quantitative data from binary scale to qualitative data

\begin{tabular}{ccc}
\hline Score Interval & \multicolumn{2}{c}{ Category } \\
\hline$\geq 0.836$ & Very Appropriate & Very Relevant \\
$0.612-0.835$ & Appropriate & Relevant \\
$0.388-0.611$ & Neutral & Neutral \\
$0.164-0.387$ & Inappropriate & Irrelevant \\
$\leq 0.163$ & Very Inappropriate & Very \\
& & Irrelevant \\
\hline
\end{tabular}

In table 2 , Mean, $\bar{X}=(0+1) / 2=1 / 2=0.50$ and Standard Deviation $=\sqrt{ }\left\{\sum(\mathrm{X}-\overline{\mathrm{X}})^{2} /(\mathrm{n}\right.$ 1) $\}=0.70$

In the Likert scale the points were assigned to numerical values from 1 to 5 , as follows:

Table 3. Scoring category in the Likert scale

\begin{tabular}{cc}
\hline Category & Score \\
\hline Very Good & 5 \\
Good & 4 \\
Average & 3 \\
Poor & 2 \\
Very Poor & 1 \\
\hline
\end{tabular}

These scores were fine grained to a five-point scale according to Table 4.

Table 4. Conversion criteria for the Likert scale

\begin{tabular}{cc}
\hline Score Interval & Category \\
\hline $\mathrm{X} \geq \overline{\mathrm{X}}+0.75 \mathrm{SD}$ & Excellent \\
$\overline{\mathrm{X}}+0.25 \mathrm{SD}<\mathrm{X}<\overline{\mathrm{X}}+0.75 \mathrm{SD}$ & Good \\
$\overline{\mathrm{X}}-0.25 \mathrm{SD}<\mathrm{X}<\overline{\mathrm{X}}+0.25 \mathrm{SD}$ & Average \\
$\overline{\mathrm{X}}-0.75 \mathrm{SD}<\mathrm{X}<\overline{\mathrm{X}}-0.25 \mathrm{SD}$ & Fair \\
$\mathrm{X} \leq \overline{\mathrm{X} \boldsymbol{u}}-0.75 \mathrm{SD}$ & Poor \\
\hline
\end{tabular}


In table $4, \overline{\mathrm{X}}$ is mean and SD is standard deviation.

Based on the conversion in Table 4, the conversion of quantitative data to qualitative data is shown in Table 5.

Table 5. Conversation of quantitative data from Likert scale to qualitative data

\begin{tabular}{cc}
\hline Score Interval & Category \\
\hline$\geq 4.20$ & Excellent \\
$3.40-4.19$ & Good \\
$2.61-3.39$ & Average \\
$1.82-2.60$ & Fair \\
$\leq 1.81$ & Poor \\
\hline
\end{tabular}

In table 5 , Mean, $\bar{X}=(1+2+3+4+5) / 5=$ $15 / 5=3.0$ and Standard Deviation $=$ $\sqrt{ }\left\{\sum\left(\mathrm{X}-\overline{\mathrm{X}}^{2} /(\mathrm{n}-1)\right\}=1.58\right.$

Data from Alpha testing and Beta testing revealed appropriateness of the elearning and data from pre-test and post-test revealed effectiveness of the e-learning.

\section{Findings and Discussion}

This research and development study was to design and implement an e-learning portal for vocational high school in Yogyakarta, Indonesia, where the target audiences were the students of class XI and teachers. The e-learning portal was developed by using Moodle 2.4.4 program with Team Builder module, with the help of a number of other programs to create contents, then it was hosted online at http://www.opaqueshadow.com/smkk/.

\section{Data from Field Study}

There were $51.1 \%$ teachers (23 out of 45 ) and $86.7 \%$ students of grade XI (104 out of 121) of Koperasi Vocational High School who were interviewed using questionnaires. Data from teachers-students interview and the practical field study showed that:

All 104 students answered that teachers usually use only lecture method to deliver instruction and $62.5 \%$ answered that the instructional process does not use any instructional media. Students lack motivation to the current teaching-learning method, which is, lecture method. Besides, 94.2\% answered that they feel not motivated to learn when learning materials are delivered using only traditional methods like lecture or discussion. Other 5.8\% answered that they feel very little motivated to learn when teachers use only lecture or discussion. Then, $82.7 \%$ students also stated that the current instructional process lacks variation in presenting learning materials. From this finding, it can be assumed that the regular academic activities of the school are monotonous. The repeated use of a method to deliver abstract materials can decrease students' motivation to learn, while discussing this matter with some students verbally expressed that the current process of presenting materials is monotonous and less attractive.

To support learning process, according to $99 \%$ students, the existing instructional media is less than sufficient, and even $67.3 \%$ among them think it is very insufficient. The insufficiency of instructional media can make learning process less interesting and can be hindrance for the learning process to achieve good quality. Among all students, 75\% answered that instructional process rarely involved the use of audio-visual materials and $96.2 \%$ students answered that audio-visual media that had been used was very difficult to use. Meanwhile, audio-visual materials have potential to make learning process of an abstract topic very interesting and easy. The more frequent use of easy-to-use audio-visual materials can really help the success of the learning process.

It was admitted by $34.8 \%$ teachers that they usually use lecture method in classroom and $60.9 \%$ admitted that they also use discussion method in classroom. In answering the question about use of audiovisual materials in classroom, $56.5 \%$ teachers admitted that they sometime use audio-visual materials in classroom, while $21.7 \%$ teachers admitted that they never used any audiovisual material to deliver instruction. Therefore, $95.7 \%$ teachers admitted they involve very frequent use of lecture and discussion method in classroom and less frequent or no use of audio-visual materials. This finding supports earlier opinions stated by students about learning process which is not having variety, which can lead to 
uninteresting learning process and result in students' lack of motivation to learn.

It was revealed that $88.5 \%$ students access internet every day and 100\% students own at least 1 internet-enabled gadget. The researcher observed that all the students have Facebook and/or Twitter account and they seem to appear online from morning till night using internet-enabled hand phones. However, $45.2 \%$ answered that they never use internet to obtain any learning materials, $6.7 \%$ answered they rarely use internet to obtain learning materials and $31.7 \%$ answered they sometime use internet to obtain learning materials. Among all students, $76 \%$ answered that the school does not provide any facility for students to acquire learning materials using internet, while other $24 \%$ answered that the school provides wireless internet access (wi-fi) and there is a computer lab in school but the school does not provide any digital material or materials over the internet. While discussing this topic, students expressed that the use of internet and computer lab in school is not optimal because the school does not provide any elearning facility via internet.

In another question, $92.3 \%$ students expressed that an e-learning website with chat, forum, blog, assignment, learning materials, quiz, and other facilities will help improving their learning process. Interview which were conducted for the teachers revealed $30.4 \%$ teachers are regular internet users and $43.5 \%$ of them use internet once in a week. It is safe to say that $87 \%$ teachers use internet at least once in a month. Meanwhile, $13 \%$ teachers admitted that they never use internet. In another question of how frequent teachers use internet to obtain instructional materials, $65.2 \%$ of them answered sometimes and $17.4 \%$ answered rarely. Whereas, $8.7 \%$ teachers answered they never use internet to obtain instructional materials. According to $91.3 \%$ teachers, the school provides facilities for teachers to acquire instructional materials using internet. They mentioned Wi-Fi as the provided facility. Yet, $8.7 \%$ teachers did not respond that question. The observation showed that all teachers own at least one internet-enabled device like hand phone, tablet PC, laptop or netbook, desktop PC, etc. In their interviews, 91.3\% teachers made positive response that an elearning website with chat, forum, blog, assignment, learning materials, quiz, and other facilities will help improving teachinglearning process. Therefore, the school provides internet access, both teachers and students have electronic gadgets, but the whole system lacks an e-learning system which is not provided by the school. Whereas, e-learning which can combine all these learning elements can ensure a better, easier and interesting learning process by providing online learning materials.

In response to an interview question, $96.2 \%$ students think being supervised by teachers only in school time is not sufficient. It was expressed by $95.2 \%$ students that being able to conduct group study will benefit their learning process. Teachers usually assign members to groups based on students' index number, but 99\% students expressed that they usually feel that their groups are not balanced and 100\% students agreed that it would be better if they can work in balanced groups. Negative responses were given by $73.9 \%$ teachers to the question that being supervised by teachers only in school time is sufficient for students. In answering the question about group study of students, $95.7 \%$ teachers agreed that being able to conduct group study is beneficial to students' learning process. They also agreed that while assigning group task, they usually feel that groups are not balanced and it'll improve students' performance if students can work in balanced groups. Group studies can increase cooperation between students but working in a not balanced group can severely affect the quality of learning.

Data from Product Testing

\section{Data from Media Validation (alpha test)}

Media validation of the e-learning had been conducted by a Professor on media specialist from the Department of Instructional Technology, in Yogyakarta State University, on May 18, 2013. Media validation consisted of 05 aspects along with 30 considerations. The results of the media 
validation which were conducted by the media specialist were illustrated in Table 6 .

Table 6. Validation of media (all aspects)

\begin{tabular}{|c|c|c|c|c|c|}
\hline ZZ1 & 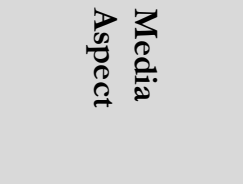 & $\begin{array}{l}H \\
0 \\
D \\
0 \\
\infty \\
0 \\
0 \\
0\end{array}$ & $\begin{array}{l}\stackrel{-1}{\circ} \\
\stackrel{D}{D} \\
\overrightarrow{0} \\
\stackrel{0}{3}\end{array}$ & 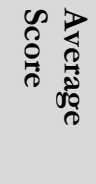 & 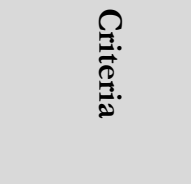 \\
\hline 1 & Appropriateness & 8 & 9 & 0.889 & $\begin{array}{l}\text { Very } \\
\text { Appropriate }\end{array}$ \\
\hline 2 & $\begin{array}{l}\text { Accuracy and } \\
\text { Clarity }\end{array}$ & 5 & 5 & 1.000 & $\begin{array}{l}\text { Very } \\
\text { Appropriate }\end{array}$ \\
\hline 3 & $\begin{array}{l}\text { Screen } \\
\text { Presentation and } \\
\text { Design }\end{array}$ & 9 & 9 & 1.000 & $\begin{array}{l}\text { Very } \\
\text { Appropriate }\end{array}$ \\
\hline 4 & $\begin{array}{l}\text { Appropriateness } \\
\text { of the Team } \\
\text { builder module }\end{array}$ & 7 & 7 & 1.000 & $\begin{array}{l}\text { Very } \\
\text { Appropriate }\end{array}$ \\
\hline & $\begin{array}{c}\text { Average of } \\
\text { average scores }\end{array}$ & & & 0.972 & $\begin{array}{l}\text { Very } \\
\text { Appropriate }\end{array}$ \\
\hline
\end{tabular}

Data from Content V alidation (alpha test)

Content validation of the multimedia product had been done by a content and instructional expert who is also an Associate professor in Yogyakarta State University, on May 18, 2013. Content validation consisted of 02 aspects along with 17 considerations. The results of the content and instruction validation are illustrated in Table 7 .

Table 7. Validation of content (all aspects)

\begin{tabular}{|c|c|c|c|c|c|}
\hline Z & 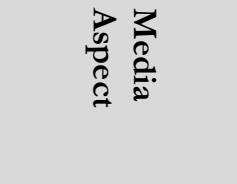 & $\begin{array}{l}-1 \\
0 \\
\stackrel{+}{0} \\
\infty \\
0 \\
0 \\
0\end{array}$ & 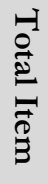 & 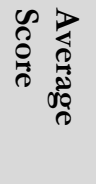 & 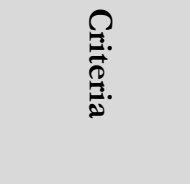 \\
\hline 1 & Appropriateness & 10 & 10 & 1.000 & $\begin{array}{l}\text { Very } \\
\text { Appropriate }\end{array}$ \\
\hline 2 & $\begin{array}{l}\text { Accuracy and } \\
\text { Clarity } \\
\text { Average of } \\
\text { average scores }\end{array}$ & 6 & 7 & $\begin{array}{l}0.857 \\
\mathbf{0 . 9 2 8}\end{array}$ & $\begin{array}{l}\text { Very } \\
\text { Appropriate } \\
\text { Very } \\
\text { Appropriate }\end{array}$ \\
\hline
\end{tabular}

Besides, based on the data which are revealed from content validation, there are some suggestions which are made to improve the content and instructional aspect of the elearning. The content \& instructional expert suggested not to use any informal word in the e-learning, to check that the materials which were used in the e-learning are really used at the school, to check and look for small grammatical mistakes (punctuation marks and spelling). The general comment, given by the content $\&$ instructional expert, was that the e-learning is good and eligible for the study in accordance with the proper revision.

Data from validation of other instruments

\section{$V$ alidation of Pre-test and Post-test instrument}

Instrument validation of the pre-test and post-test instrument had been conducted by an associate professor of Yogyakarta State University, on May 18, 2013. The pre-test and post-test instrument consisted of 9 multiple choice questions. The result of the instrument validation of the pre-test and post-test instrument is presented in Table 8.

Table 8. Validation of the pre-test and posttest instrument (all items)

\begin{tabular}{clcccl}
\hline No & Item & $\begin{array}{c}\text { Total } \\
\text { Score }\end{array}$ & $\begin{array}{c}\text { Total } \\
\text { Item }\end{array}$ & $\begin{array}{c}\text { Average } \\
\text { Score }\end{array}$ & Criteria \\
\hline 1 & $\begin{array}{l}\text { All } \\
\text { quest- } \\
\text { ions }\end{array}$ & 9 & 9 & 1.000 & $\begin{array}{l}\text { Very } \\
\text { Re- } \\
\text { levant }\end{array}$ \\
\hline
\end{tabular}

Validation of Beta testing by students instrument

Instrument validation of the beta testing by students instrument had been conducted by two experts: a professor from the Department of Instructional Technology in Yogyakarta State University, and an associate professor who also comes from Yogyakarta State University, on May 18, 2013. The result of the instrument validation of beta testing by students instrument (all items) is illustrated in Table 9.

Table 9. Validation of the beta testing by students instrument (all items)

\begin{tabular}{cccccc}
\hline No & Item & $\begin{array}{c}\text { Total } \\
\text { Score }\end{array}$ & $\begin{array}{c}\text { Total } \\
\text { Item }\end{array}$ & $\begin{array}{c}\text { Average } \\
\text { Score }\end{array}$ & Criteria \\
\hline 1 & $\begin{array}{l}\text { All } \\
\text { quest- } \\
\text { ions }\end{array}$ & 13 & 13 & 1.000 & $\begin{array}{l}\text { Appry } \\
\text { priate }\end{array}$ \\
\hline
\end{tabular}

Validation of Beta testing by teachers instrument

Instrument validation of the beta testing by teachers instrument had been conducted by two experts: a professor from the Department of Instructional Technology of Yogyakarta State University and an associate professor from Yogyakarta State University, on May 18, 2013. The result of 
validation of the beta testing by teachers instrument (all items) is presented in Table 10.

Table 10. Validation of the beta testing by teachers instrument (all items)

\begin{tabular}{cccccl}
\hline No & Item & $\begin{array}{c}\text { Total } \\
\text { Score }\end{array}$ & $\begin{array}{c}\text { Total } \\
\text { Item }\end{array}$ & $\begin{array}{c}\text { Average } \\
\text { Score }\end{array}$ & Criteria \\
\hline 1 & $\begin{array}{l}\text { All } \\
\text { items }\end{array}$ & 18 & 18 & 1.000 & $\begin{array}{l}\text { Very } \\
\text { Appro- } \\
\text { priate }\end{array}$ \\
\hline
\end{tabular}

$V$ alidation of the instrument to create balanced groups using Team builder

Instrument validation to create balanced groups by employing Team builder had been conducted by two experts: a professor from the Department of Instructional Technology in Yogyakarta State University and an associate professor who comes also from Yogyakarta State University, on May 18, 2013. There were five questions in this instrument. The results of the validation are illustrated in Table 11.

Table 11. Validation of the instrument to create balanced groups using Team builder (all items)

\begin{tabular}{cccccl}
\hline No & Item & $\begin{array}{c}\text { Total } \\
\text { Score }\end{array}$ & $\begin{array}{c}\text { Total } \\
\text { Item }\end{array}$ & $\begin{array}{c}\text { Average } \\
\text { Score }\end{array}$ & Criteria \\
\hline 1 & $\begin{array}{l}\text { All } \\
\text { items }\end{array}$ & 5 & 5 & 1.000 & $\begin{array}{l}\text { Very } \\
\text { Relevant }\end{array}$ \\
\hline
\end{tabular}

$V$ alidation of Need Assessment by students instrument

Instrument validation of the Need Assessment by students instrument had been done by two experts: a professor from the Department of Instructional Technology in Yogyakarta State University and an associate professor from the same university, on May 18, 2013. There were 18 items in this instrument. The results of the instrument validation of the Need Assessment by students instrument are illustrated in Table 12.

Table 12. Validation of the Need Assessment by students instrument (all items)

\begin{tabular}{cccccl}
\hline No & Item & $\begin{array}{c}\text { Total } \\
\text { Score }\end{array}$ & $\begin{array}{c}\text { Total } \\
\text { Item }\end{array}$ & $\begin{array}{c}\text { Average } \\
\text { Score }\end{array}$ & Criteria \\
\hline 1 & $\begin{array}{l}\text { All } \\
\text { items }\end{array}$ & 18 & 18 & 1.000 & $\begin{array}{l}\text { Very } \\
\text { Relevant }\end{array}$ \\
\hline
\end{tabular}

$V$ alidation of Need Assessment by teachers instrument

Instrument validation of the Need Assessment by teachers instrument had been done by two experts: a professor from the Department of Instructional Technology in Yogyakarta State University, and an associate professor from the same university, on May 18, 2013. There were 18 items in this instrument. The results of the instrument validation of the Need Assessment by teachers instrument are illustrated in Table 13.

Table 13. Validation of the Need Assessment by teachers instrument (all items)

\begin{tabular}{cccccc}
\hline No & Item & $\begin{array}{c}\text { Total } \\
\text { Score }\end{array}$ & $\begin{array}{c}\text { Total } \\
\text { Item }\end{array}$ & $\begin{array}{c}\text { Average } \\
\text { Score }\end{array}$ & Criteria \\
\hline 1 & $\begin{array}{l}\text { All } \\
\text { items }\end{array}$ & 18 & 18 & 1.000 & $\begin{array}{l}\text { Very } \\
\text { Relevant }\end{array}$ \\
\hline
\end{tabular}

Data from Beta Test

Beta testing by students

Beta testing by students was conducted by 48 students of class XI of Koperasi Vocational High School, Yogyakarta, Indonesia. These students were selected by using simple random sampling. There are 6 sections of class XI; accounting 1, accounting 2 , accounting 3 , marketing 1 , marketing 2 and visual communication design. From each section, 8 students were randomly selected for beta testing. Total of 40\% (48 out of 120) students of class XI participated in beta testing and they represented the target audiences for which this e-learning was intended. The obtained data from the beta testing by students are clearly illustrated in Table 14.

Table 14. Results of the Beta Testing by students (all aspects)

\begin{tabular}{llcl}
\hline No & \multicolumn{1}{c}{ Aspect } & $\begin{array}{c}\text { Average } \\
\text { Score }\end{array}$ & Criteria \\
\hline 1 & Appropriateness & 4.38 & Excellent \\
2 & Accuracy and Clarity & 4.44 & Excellent \\
3 & $\begin{array}{l}\text { Screen Presentation } \\
\text { and Design }\end{array}$ & 4.46 & Excellent \\
4 & $\begin{array}{l}\text { Appropriateness of } \\
\text { the Team builder } \\
\text { module } \\
\text { Average of average } \\
\text { scores }\end{array}$ & 4.48 & Excellent \\
$\quad$ 4.44 & Excellent \\
\hline
\end{tabular}




\section{Beta testing by teachers}

Beta testing by teachers was conducted by 9 teachers of Koperasi Vocational High School, Yogyakarta, Indonesia. These teachers were selected using simple random sampling. Total $20 \%$ (9 out of 45 ) teachers participated in beta testing. The obtained data from the beta testing by teachers are illustrated in Table 15.

Table 15. Results of the Beta Testing by teachers (all aspects)

\begin{tabular}{llcl}
\hline No & \multicolumn{1}{c}{ Aspect } & $\begin{array}{c}\text { Average } \\
\text { Score }\end{array}$ & Criteria \\
\hline 1 & Appropriateness & 4.60 & Excellent \\
2 & Accuracy and Clarity & 4.44 & Excellent \\
3 & $\begin{array}{l}\text { Screen Presentation } \\
\text { and Design }\end{array}$ & 4.59 & Excellent \\
4 & $\begin{array}{l}\text { Appropriateness of } \\
\text { the Team builder } \\
\text { module } \\
\text { Average of average } \\
\quad \text { scores }\end{array}$ & 4.56 & Excellent \\
\multicolumn{2}{c}{4.55} & Excellent \\
\hline
\end{tabular}

Data of Learners' Achievement

The aspiration of the e-learning was to improve the learning quality as well as to increase students' achievements. The whole evaluation phase was dedicated to determine whether this e-learning was able to improve students' achievements. The following procedures were taken in executing evaluation phase: (a) pre-test was done to identify the learners' understanding about the concepts which they would learn afterward, (b) students learned the topics through the developed e-learning, (c) post-test was done to know students' understanding about the contents that they learned, (d) comparing the results of pre-test and post-test, effectiveness of the e-learning was determined. The pretest and post-test were conducted by $42 \%$ (50 out of 120) students of class XI, Koperasi Vocational High School, Sleman, Yogyakarta, Indonesia. The questions used in the pre-test and post-test were same and consisted of nine multiple choice questions (MCQ).

Data Analysis

\section{Data Analysis of the Alpha Test}

Data from the alpha test of the elearning (both media validation by the media specialist, and content and instructional validation by the content expert) were used to improve the e-learning the aspects of: appropriateness, accuracy and clarity, screen presentation and design, and the team builder module's appropriateness.

There were 04 core aspects including 30 considerations for the alpha test of media. All of the 04 aspects were judged "Very Appropriate", explicitly: (a) appropriateness 0.889 (out of 1), (b) accuracy and clarity 1.000 (out of 1), (c) screen presentation and design 1.000 (out of 1), and (d) appropriateness of the team builder module 1.000 (out of 1 ). Where the overall average scores of the media aspect was 0.972 (out of 1) (Very Appropriate). Meanwhile, out of 30 considerations, only one consideration $(3.33 \%)$ scored 0 (Not Appropriate), the rest of 29 considerations $(96.67 \%)$ scored 1 (Appropriate).

There were 02 core aspects including 17 considerations for the alpha test of content and instruction aspect. All of the 02 aspects were judged 'Very Appropriate', namely: (a) appropriateness 1.000 (out of 1), and (b) accuracy and clarity 0.857 (out of 1). Where the overall average scores of the content aspect was 0.928 (out of 1) (Very Appropriate). Meanwhile, out of 17 considerations, only 01 consideration $(5.88 \%)$ scored 0 (Not Appropriate), the rest of 16 considerations $(94.11 \%)$ scored 1 (Appropriate).

The appropriateness of the content and instructional aspect of this instructional multimedia product was Very Appropriate with average score of 0.928 (out of 1 ), along with the appropriateness of the media aspect was Very Appropriate with average score 0.972 (out of 1) and the overall appropriateness of the e-learning was Very Appropriate with the average score of 0.950 (out of 1). However, the e-learning was further improved based on the suggestions by both media specialist and also content and instructional expert. 


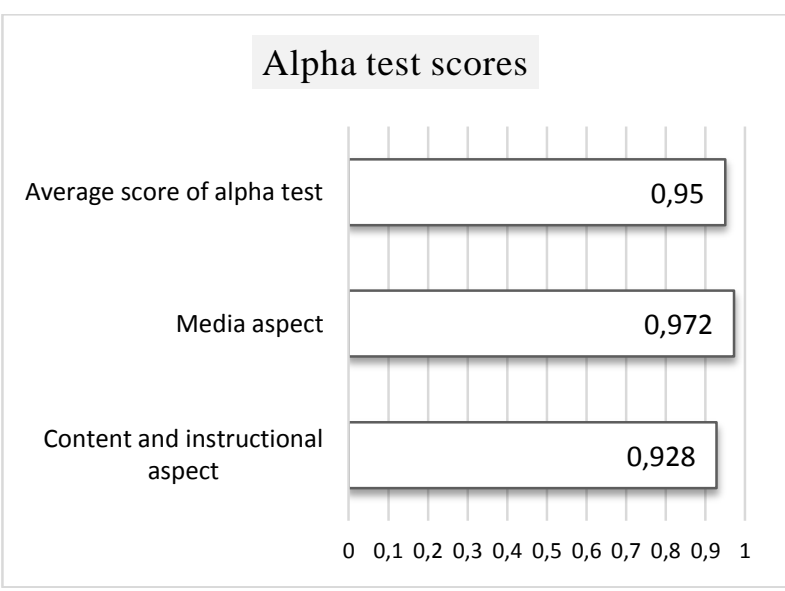

Figure 1. Appropriateness of the e-learning from the alpha testing

\section{Data Analysis of the Beta Test}

Beta Test was conducted by two types of users of the e-learning, that are, the students and teachers. Beta testing by students was conducted by $40 \%$ (48 out of 120) students of class XI of Koperasi Vocational High School. Based on the results from beta testing by students, the e-learning is Excellent, in which the overall average score is 4.44 on the scale of 1 to 5 . The average scores of all the aspects in beta testing by students are clearly presented in Table 16.

Table 16. Quality of the e-learning from Beta Testing by students

\begin{tabular}{clcl}
\hline No & \multicolumn{1}{c}{ Aspect } & $\begin{array}{c}\text { Average } \\
\text { Score }\end{array}$ & Criteria \\
\hline 1 & Appropriateness & 4.38 & Excellent \\
2 & Accuracy and Clarity & 4.44 & Excellent \\
3 & $\begin{array}{l}\text { Screen Presentation } \\
\text { and Design }\end{array}$ & 4.46 & Excellent \\
4 & $\begin{array}{l}\text { Appropriateness of } \\
\text { the Team builder } \\
\text { module }\end{array}$ & 4.48 & Excellent \\
& $\quad$ Overall & 4.44 & Excellent \\
\hline
\end{tabular}

Beta testing by teachers was conducted by 20\% (9 out of 45) teachers of Koperasi Vocational High School, Yogyakarta, Indonesia. Based on the results from beta testing by teachers, the e-learning is Excellent, in which the overall average score is 4.55 on a scale of 1 to 5 . The average scores of aspects in beta testing by teachers are clearly presented in Table 17.
Table 17. Quality of the e-learning from the Beta Testing by teachers

\begin{tabular}{clcl}
\hline No & \multicolumn{1}{c}{ Aspect } & $\begin{array}{c}\text { Average } \\
\text { Score }\end{array}$ & Criteria \\
\hline 1 & Appropriateness & 4.60 & Excellent \\
2 & Accuracy and Clarity & 4.44 & Excellent \\
3 & $\begin{array}{l}\text { Screen Presentation } \\
\text { and Design }\end{array}$ & 4.59 & Excellent \\
4 & $\begin{array}{l}\text { Appropriateness of } \\
\text { the Team builder }\end{array}$ & 4.56 & Excellent \\
& module & & \\
$\quad$ Overall & $\mathbf{4 . 5 5}$ & Excellent \\
\hline & & &
\end{tabular}

The overall quality and performance of the elearning revealed by beta test is Excellent with a score of 4.495 out of 5 .

Table 18. Overall quality of the e-learning from Beta Testing

\begin{tabular}{cccc}
\hline No & \multicolumn{1}{c}{ Aspect } & Score & Criteria \\
\hline 1 & $\begin{array}{l}\text { Average score from beta } \\
\text { testing by students } \\
\text { Average score from beta } \\
\text { testing by teachers }\end{array}$ & 4.44 & Excellent \\
Overall & 4.55 & Excellent \\
\hline & Excellent \\
\hline
\end{tabular}

Data Analysis of Learners' Achievement

To find out the effectiveness of the elearning, in evaluation phase, pre-test was taken before applying the e-learning and post-test was taken after applying e-learning.

Table 19. Mean, Maximum and Minimum scores of pre-test and post-test

\begin{tabular}{|c|c|c|c|c|}
\hline & & $\begin{array}{l}\text { Pre- } \\
\text { test }\end{array}$ & $\begin{array}{c}\text { Post- } \\
\text { test }\end{array}$ & Difference \\
\hline \multirow[t]{2}{*}{$\mathrm{N}$} & Valid & 50 & 50 & \\
\hline & Missing & 0 & 0 & \\
\hline \multicolumn{2}{|c|}{ Mean } & 5.02 & 8.84 & 3.82 \\
\hline \multicolumn{2}{|c|}{ Minimum } & 3.00 & 8.00 & 5.00 \\
\hline \multicolumn{2}{|c|}{ Maximum } & 7.00 & 9.00 & 2.00 \\
\hline
\end{tabular}

PRE-TEST AND POST-TEST SCORES

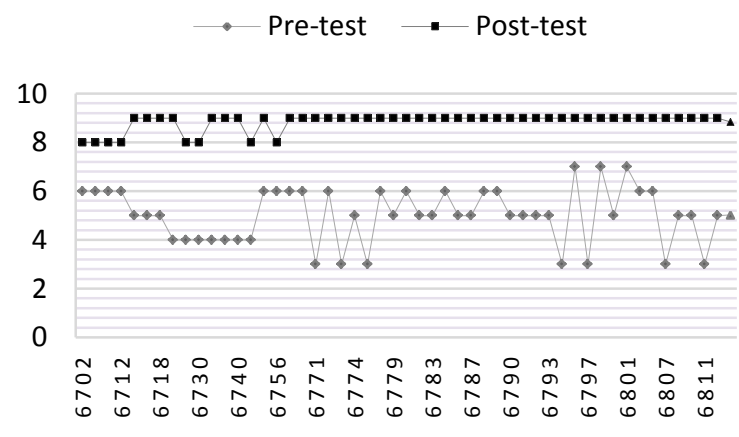

Figure 2. Pre-test and post-test scores 
Table 19 and figure 2 shows that the average score of pre-test was 5.02 (out of 9) and post-test was 8.84 (out of 9). The average score of students raised 3.82 points (post-test average score - pre-test average score, i.e., $8.84-5.02=3.82$ ) or $42.44 \%$ in the post-test from pre-test score, the minimum score of students raised 5 points (minimum score in post-test - minimum score in pre-test, i.e. 8$3=5$ ) after using the e-learning, and the maximum score of students raised 2 points (minimum score in post-test - minimum score in pre-test, i.e. 9-7=2) after using the elearning. Table 19 and figure 2 also shows that, the minimum score of post-test (i.e. 8) is higher than the maximum score of pre-test (i.e. 7), so it proves that the use of e-learning did not deteriorate the performance of any student. It also indicates that performance of students improved after using the e-learning and the e-learning was highly effective.

\section{Analysis of Data from Instruments V alidation}

All the instruments to conduct this study and to collect data were validated by two validators. Instrument validations were done by two experts: a professor from the Department of Instructional Technology in a state university in Yogyakarta, and an associate professor from the same university, on May 18, 2013. On a scale of 0 to 1 , all the instruments scored perfect from both validators. The average score of each instrument is shown in Table 20.

Table 20. Quality of data collection instruments

\begin{tabular}{lcl}
\hline \multicolumn{1}{c}{ Instrument } & $\begin{array}{c}\text { Average } \\
\text { Score }\end{array}$ & \multicolumn{1}{c}{ Criteria } \\
\hline $\begin{array}{l}\text { Need Assessment } \\
\text { by teachers }\end{array}$ & 1.000 & Very Relevant \\
$\begin{array}{l}\text { Need Assessment } \\
\text { by students }\end{array}$ & 1.000 & Very Relevant \\
$\begin{array}{l}\text { Beta testing by } \\
\text { teachers }\end{array}$ & 1.000 & $\begin{array}{l}\text { Very } \\
\text { Appropriate } \\
\begin{array}{l}\text { Beta testing by } \\
\text { students }\end{array}\end{array}$ \\
$\begin{array}{l}\text { Pre-test and Post- } \\
\text { test }\end{array}$ & 1.000 & $\begin{array}{l}\text { Very } \\
\text { Appropriate }\end{array}$ \\
$\begin{array}{l}\text { Create balanced } \\
\text { groups using Team } \\
\text { builder }\end{array}$ & 1.000 & Very Relevant \\
\hline
\end{tabular}

Analysis of Appropriateness of the Team Builder Module

From alpha testing, the appropriateness of the Team Builder Module was 'Very appropriate' (score 1.0 out of 1.0). From beta testing by students, the quality of the Team Builder Module was 'Excellent' (score 4.48 out of 5.00) and from the beta testing by teachers, the quality of the Team Builder Module was 'Excellent' (score 4.56 out of 5.00). Hence, from beta testing, the overall quality of the Team Builder Module was 'Excellent' (average score 4.52 out of 5.00). Therefore, the quality of the Team Builder module was 'Excellent' and it was 'Very Appropriate' for the students.

\section{Data from Ongoing Evaluation}

To ensure good quality of the developed product, from analysis to implementation phase, there was ongoing evaluation. The evaluation was not formal and did not use a structured form. After finishing each phase and sub-phase, the researcher reviewed the work to find out errors and corrected them. Here are some corrections made during ongoing evaluation: Some students had trouble in understanding the written need assessment questionnaire, which was written in English. Thus, the researcher made a quick decision and verbally translated the questionnaire in Bahasa Indonesia. The school logo on e-learning was changed from a small black and white logo to a large logo with appropriate colors. The storyboard had a three-column web view planned for the portal but in course pages, the researcher decided to keep all blocks of right and left column collapsed by default, so that the course contents get more focus. The same theme was used for tablet devices and smart phones in order to make the users feel comfortable while using e-learning across devices. Initially, some materials were provided using word processing document files with 'docx' extension, which is used by Microsoft Office Word 2007 and above. However, some computers in school have only Microsoft Word 1997 installed in them, so those files were converted to older 'doc' format to ensure that each and every piece of 
information on the e-learning is accessible by all users. Video files were converted to relatively lower resolution, which decreased file sizes to ensure that the files can be downloaded faster and/or video feed plays smoothly using slow internet connections.

\section{Conclusion and Recommendation}

Conclusion

Based on the findings of the research, a number of conclusions are revealed as follows:

In this $\mathrm{R} \& \mathrm{D}$ study, the e-learning portal was developed through six phases, explicitly: (1) analysis, (2) planning, (3) design, (4) development, (5) implementation and (6) evaluation, for a vocational high school in Yogyakarta, Indonesia, where the target audiences were the students of class XI and teachers. The e-learning portal was developed by using Moodle 2.4.4 program with Team Builder module, then it was hosted at http://www.opaqueshadow.com/smkk/ to provide online access. The primary contents of the e-learning were three important topics of English language studies for class XI of vocational high school level in Indonesia, namely: invitation-response, bargain-response and asking and giving opinion.

Overall, the e-learning is 'Very Appropriate' from the alpha testing with overall average score of 0.95 (out of 1.00). The overall quality and appropriateness of the e-learning from the beta testing was 'Excellent' with overall average score of 4.49 (out of 5.00). The quality of the Team Builder module from alpha and beta testing was 'Excellent' and it was 'Very Appropriate' for the students. According to alpha testing results, from instructional and content aspect, the e-learning was 'Very Appropriate' with overall average score of 0.928 (out of 1.00) and from media aspect was 'Very Appropriate' with overall average score of 0.972 (out of 1.00). The quality and appropriateness of the e-learning from the beta testing by teachers was 'Excellent' with overall average score of 4.55 (out of 5.00), and by students was 'Excellent' with overall average score of 4.44 (out of 5.00). From alpha testing, the appropriateness of the
Team Builder Module was 'Very appropriate' (score 1.0 out of 1.0). From beta testing by students, the quality of the Team Builder Module was 'Excellent' (score 4.48 out of 5.00) and from beta testing by teachers, the quality of the Team Builder Module was 'Excellent' (score 4.56 out of 5.00). Hence, from beta testing, the overall quality of the Team Builder Module was 'Excellent' (average score 4.52 out of 5.00).

The e-learning is 'Highly Effective'. The average score of students raised 3.82 points (or $42.44 \%$ ) in the post-test from pretest score, the minimum score of students raised 5 points and the maximum score of students raised 2 points after using the elearning. Also, the minimum score of posttest (i.e. 8) is more than maximum score of pre-test (i.e. 7), so it could be drawn into conclusion that the use of e-learning did not deteriorate students' performance, but rather, it improved students' performance.

\section{Recommendations}

Several recommendations have been depicted depending on the mentioned conclusion of this research and development study: The design and implementation of elearning using Moodle 2.4.4 alone with the support of several expedient programs should develop in preeminent version in order to get an alternative learning resource, which can be utilized by the target audiences or students for interactive individual learning purposes. If the e-learning is vigilantly used, it could be anticipated that it will be able to improve the students' achievement. Teachers and students should be properly trained to use the e-learning. The experiment of the study was limited only in one vocational high school. Hence, for the large scale dissemination of this product, it should be needed to conduct further research and development on a wider scale (for instance, audience analysis in large scale, technology analysis, critical-incident analysis, situational analysis, extant-data analysis, and cost-benefit analysis, etc.). To be more perfect, it was needed to do further development of the product with extensive evaluation. As the components of internet are rapidly changing, 
www.moodle.org frequently releases newer versions of the software with newer and/or, more stable features. It is recommended to use the latest stable release of Moodle in future development of the e-learning. For the further development, it should combine the unlisted multimedia; for instant, in the production activities, and application.

Though this research and development study had been conducted to fulfill the partial demand of the researcher's academic work, the researcher did believe that this research work was not sufficient to develop e-learning for large dissemination. The researcher had concluded that more in depth research studies should be conducted in the broad aspects for further improvement of elearning.

\section{References}

AECT Definition and Terminology Committee. (2004, June 1). The meanings of educational technology. Retrieved on 12 April 2013, from http://opaqueshadow.com/reference s/Meanings $\% 20$ of $\% 20$ ET_4.0.pdf

Alessi, S. M., \& Trollip, S. R. (2001). Multimedia for learning: Methods and development (3rd ed.). Boston: Allyn and Bacon.

Caladine, R. (2008). Foreword. In enbancing elearning with media-rich content and interactions (3rd ed.). Hershey, USA: Information Science Publishing.

Dale, E. (1954). Audio-visual methods in teaching. New York, NY: Dryden.

IONESCU, A. (2012). New e-learning method using databases. Database Systems Journal, III(2), 35-46. Retrieved February 14, 2013, from http://www.dbjournal.ro/archive/9/ 9_4.pdf

Januszewski, A., \& Molenda, M. (2008). Educational technology: A definition with commentary. New York, NY: Lawrence Erlbaum Associates.

Moodle | Moodlerooms. (n.d.). Retrieved October 5, 2012, from Moodlerooms: http://www.moodlerooms.com/reso urces/moodle-resources/

Moodle community. (2012, December 3). Installing moodle. Retrieved December 17, 2012, from MoodleDocs: http://docs.moodle.org/24/en/Insta lling_Moodle

Moodle Statistics. (2013, June). Retrieved June 5, 2013, from Moodle.org: http://moodle.org/stats

Muijs, D., \& Reynolds, D. (2005). Effective teaching: Evidence and practice (2nd ed.). London: SAGE Publications Ltd.

Philosophy - MoodleDocs. (n.d.). Retrieved October 6, 2012, from Moodle.org: http://docs.moodle.org/en/Philosop hy

Smaldino, S. E., Lowther, D. L., \& Russell, J. D. (2008). Instructional technology and media for learning (9th ed.). New Jersey: Pearson.

Tavangarian, D., Leypold, M. E., Nölting, K., Röser, M., \& Voigt, D. (2004). Is elearning the solution for individual learning? Electronic Journal of e-Learning, 2(2), pp. 273-280. Retrieved from http://citeseerx.ist.psu.edu/viewdoc/ download?doi=10.1.1.116.8017\&rep $=$ rep1\&type $=$ pdf

Whyte, C. B. (1989). Student affairs-the future. Journal of College Student Personnel, 30(1), pp. 86-89. 